\title{
The Need for Telerehabilitation Increased During Pandemic Period: Can a Systemic Solution Be Generated?
}

\author{
Pandemi Döneminde Telerehabilitasyon ihtiyacı Arttı: Sistemik Bir Çözüm Üretilebilir Mi? \\ (1) Fatih Bağcıer, (1) Ozan Volkan Yurdakul* \\ University of Health Sciences Turkey, Başakşehir Çam and Sakura City Hospital, Clinic of Physical Medicine and Rehabilitation, İstanbul, Turkey \\ *Bezmialem Vakıf University Faculty of Medicine, Department of Physical Medicine and Rehabilitation, Istanbul, Turkey
}

\section{Dear Editor;}

"We are now in a world where new pathogens will emerge. Future pandemics will be worse than coronavirus," said Professor Jean-Jacques Muyembe Tamfum, one of the first to discover Ebola. This opinion may be the message of being ready for the future by getting messages from the past and the present. Throughout history, humankind has struggled with epidemic diseases, their material and spiritual effects on the world (1). It was necessary to produce fast and effective solutions in the forced struggle. However, as we have seen in the Coronavirus disease-2019 (COVID-19) pandemic we are in, it seems very difficult to control, organize, and eliminate the epidemic.

The physical and psychological collapse that occurs with isolation, one of the most radical struggles, ultimately activates a vicious circle. Parameters such as not exercising triggered by anxiety and depression, increase in body mass index make the person's psychology even weaker, and negatively affect the immune system (2). It is necessary to break this vicious circle at one point, and telerehabilitation can be considered as one of the most reasonable solution methods.

Telerehabilitation is a treatment method in which communication technologies such as telephone or video-teleconference are used (3). Although we frequently heard this concept during the pandemic period, it is a modality with a history dating back to the 2000's and experienced in many fields. It is the logic of providing services to those who cannot reach treatment, have transportation problems, or live in the periphery and do not have transportation. It protects risky groups and their families by keeping them away from the hospital environment, especially during the pandemic period. In the literature, telerehabilitation studies have been conducted in stroke rehabilitation, spinal cord injury, and cardiac rehabilitation $(3,4)$. An important point here is that this method cannot be used in patients who require a faceto-face physical examination or in patients with the severe clinic.
In our country, some patients were afraid of applying to the hospital during the pandemic period and whose existing disease was aggravated at home. Despite all constructive approaches in rehabilitation services, healthcare services were disrupted, and hospitals had to be transformed into pandemic services. Patients with fibromyalgia and other chronic pain syndromes whose drug reports have ended, those who have come to control time, or those who have to stay in their homes due to the pandemic's stress have experienced quite tricky days (5). During the pandemic period, obtaining information about health by applying to online platforms has gradually increased. Possible misinformation that patients acquire with this method may turn the disease into a worse clinical course. With this point of view, putting the telerehabilitation system into service in accordance with the health system helps patients reach the right information and helps the follow-up and rehabilitation of their current disease. Telerehabilitation will make us more prepared for the ongoing COVID-19 pandemic and the future.

Keywords: Telerehabilitation, pandemic, rehabilitation Anahtar kelimeler: Telerehabilitasyon, pandemi, rehabilitasyon

Peer-review: Externally and internally peer-reviewed.

Conflict of Interest: No conflict of interest was declared by the authors.

Financial Disclosure: The authors declared that this study has received no financial support.

\section{References}

1. Kesiktaş FN, Bilir Kaya B. Telerehabilitasyon. Ayhan FF, Demirbağ Kabayel D, editors. COVID-19 pandemisi ve fiziksel tıp ve rehabilitasyon. $1^{\text {st }}$ ed. Ankara: Türkiye Klinikleri; 2020. p. 89-93.

2. Laddu DR, Lavie CJ, Phillips SA, Arena R. Physical activity for immunity protection: Inoculating populations with healthy living medicine in preparation for the next pandemic. Prog Cardiovasc Dis 2021;64:102-4.

Address for Correspondence/Yazışma Adresi: Fatih Bağcıer MD, University of Health Sciences Turkey, Başakşehir Çam and Sakura City Hospital, Clinic of Physical Medicine and Rehabilitation, İstanbul, Turkey

Phone: +90 5442429042 E-mail: bagcier_42@hotmail.com ORCID ID: orcid.org/0000-0002-6103-7873

Received/Geliş Tarihi: 07.01.2021 Accepted/Kabul Tarihi: 14.04.2021

${ }^{\circ}$ Copyright 2021 by the Turkish Osteoporosis Society / Turkish Journal of Osteoporosis published by Galenos Publishing House 
3. Chang MC, Boudier-Revéret M. Usefulness of Telerehabilitation for Stroke Patients During the COVID-19 Pandemic. Am J Phys Med Rehabil 2020;99:582.

4. Thomas E, Gallagher R, Grace SL. Future-proofing cardiac rehabilitation: Transitioning services to telehealth during COVID-19. Eur J Prev Cardiol 2020;23:2047487320922926.
5. Clauw DJ, Häuser W, Cohen SP, Fitzcharles MA. Considering the potential for an increase in chronic pain after the COVID-19 pandemic. Pain 2020;161:1694-7. 